\title{
DAYA TARIK DESAIN KARAKTER “SI METON”
}

\author{
Hasbullah $^{1}$, Hendra Santosa ${ }^{2}$, I Wayan Swandi ${ }^{3}$ \\ ${ }^{123}$ Program Studi Seni, Program Magister Program Pascasarjana \\ 2Program Studi Seni Karawitan \\ ${ }^{3}$ Program Studi Desain Komunikasi Visual \\ Institut Seni Indonesia Denpasar, Jl. Nusa Indah Denpasar, Kota Denpasar, Bali 80235 \\ hendrasnts@gmail.com
}

\begin{abstract}
Abstrak: Desain Karakter "Si Meton" merupakan pemenang sayembara jingle dan maskot yang diselenggarakan KPUD Provinsi NTB tahun 2017. Meskipun "Si Meton" menggambarkan patron budaya sebagai daya tarik promosi Pilkada NTB tahun 2018, rupanya belum tentu dapat dipahami sebagian besar masyarakat NTB. Permasalahan yang diangkat pada penelitian ini akan menyorot daya tarik desain karakter "Si Meton" yang mendapat juara pertama pada sayembara jingle dan maskot yang diselenggarakan KPUD NTB tahun 2017. Metode yang digunakan dalam penelitian ini adalah metode kualitatif dengan landasan teori estetika postmodern Piliang dan teori prinsip penggambaran karakter animasi Walt Disney. Hasilnya, terdapat daya tarik dua unsur budaya yang berbeda yaitu budaya masa lalu membentuk keindahan yang mengarah pada pastiche dan parodi dengan membentuk penjiwaan karakter yang baru. Manfaat penelitian ini untuk mengembangkan pemahaman daya tarik dari keindahan pastiche, parodi dan kesan yang tercipta dalam desain karakter.

Kata Kunci: Daya Tarik, Desain karakter, "Si Meton", Parodi, Pastiche.
\end{abstract}

\begin{abstract}
Si Meton" is a character design that has won the jingle and mascot contest held by the NTB Provincial Election Commission in 2017. Although "Si Meton" portrayed cultural patron as an attraction for promotion of the NTB Regional Election in 2018, it is not necessarily to be understood by most of the people of NTB. The problem raised in this study is centered to the attractiveness aspect of the "Si Meton" character design, which won first place in the jingle and mascot competition held by the 2017 Election Commission of West Nusa Tenggara. The method used in this study is a qualitative method with the foundation of Piliang postmodern aesthetic theory and the principle theory of Walt Disney's animated character description. As a result, there are attractions of two different cultural elements: the culture of the past shaping the beauty that leads to pastiche and parody by forming a new character sentiment. The benefits of this research are to develop an understanding of the attractiveness of the beauty of pastiche, satire, and the impression created in character design.
\end{abstract}

Keywords: Attractiveness, Character design, "Si Meton", Parody, Pastiche. 


\section{PENDAHULUAN}

Perkembangan ilmu pengetahuan dan teknologi menjadikan berkembangnya pola pikir manusia, untuk meningkatkan daya dan pemahaman. Selama manusia selalu ingin tahu dengan mengajukan pertanyaan-pertanyaan seperti 'apa', 'mengapa', 'bagaimana', 'dimana' dan 'bilamana maka menjadikan hal tersebut menarik' (Sumaryono, 1999). Menariknya fenomena yang dialami sebagai suatu pengalaman, membuat tingkat pengetahuan menjadi bertambah. Tanpa disadari pengalaman dalam hidup begitu beragam, mengajak otak untuk bekerja menghasilkan ide-ide yang berbeda dari yang sudah ada. Perbedaan tersebut, menjadikan tolok ukur perkembangan daya khayal dan daya pembelajaran bagi hidup yang selalu ditemani dengan hal-hal yang menarik.

Hidup selalu menginginkan hal unik dan indah sebagai suatu yang pengalaman yang berbeda dari yang bentuk yang realistis. Terkadang, bentuk yang nyata dimodifikasi semenarik mungkin dan berbeda dari aslinya. Perbedaan tersebut diidentikkan Deleuze sebagai perbedaan yang dibangun tanpa ikatan dengan sebuah determinasi di luar dirinya disebut sebagai perbedaan bebas (Piliang, 2019). Perbedaan yang ekstrim juga dapat dikombinasikan secara harmonis melalui pendekatan dan teknik yang dapat merangkul perbedaan yang ada. Melalui perbedaan, baik unsur sosial, budaya maupun unsur desain yang membentuk dalam satu karya seni, bukanlah hal yang menjadikan tidak indah. Tetapi, adanya perbedaan tersebut menjadikan akan lebih menarik dan indah.

Nilai-nilai keindahan tercipta melalui perasaan dan pikiran yang diolah dengan daya kreativitas oleh pencipta karya seni (seniman). Dalam seni, perasaan harus dikuasai terlebih dahulu, harus dijadikan objek, dan harus diatur, dikelola, dan diwujudkan atau didaya-tarik-estetikkan dalam karya seni (Sumardjo, 2000). Pengelolaan perasaan melalui estetik dapat menghasilkan 
satu karya yang indah dan menarik. Faktor yang menimbulkan nilai suatu karya seni dan desain terlihat pada keteguhan prinsip yang mengkomposisikan unsur. Karya desain dikatakan menarik apabila semua unsur yang ada saling melengkapi dan seimbang. Desain harus memiliki keseimbangan agar nyaman dipandang dan tidak membuat gelisah (Anggraini dan Nathalia, 2014). Kenyamanan mata memandang, bukan menjadi hal yang gampang. Tetapi, melalui kenyamanan tersebut akan muncul perasaan yang senang dan menimbulkan nilai keindahan pada pandangan.

Tema desain karakter tersebut, mengambil salah satu kearifan lokal dari bahasa Bali dan Sasak yaitu Semeton. Menurut Budiwanti (2018), kata Semeton yang berarti saudara atau kerabat, maksudnya bahwa suku Bali yang tinggal di Lombok menganggap Orang Sasak bukan siapa-siapa, semua adalah saudara. Biasanya Orang Sasak memanggil batur Bali dan Orang Bali memanggil batur Sasak. Secara budaya sudah menggambarkan satu keindahan yang berbudaya harmonis. Semeton merupakan panggilan seharihari di daerah Kota Mataram dan sekitarnya. Hal itu terjadi, karena di Kota Mataram hidup berdampingan suku Sasak, Samawa, Mbojo, Bali dan lain sebagainya. Kata Semeton kerap dijadikan bahasa keseharian, agar tercipta kedamaian antar masyarakat yang tinggal di Mataram. Hal tersebut, juga digambarkan dalam slogan Kota Mataram yang berbunyi "Mataram Maju, Religius, dan Berbudaya". Berangkat dari slogan berbudaya tersebut, yang menggambarkan beraneka ragam suku yang tinggal di dalamnya. Sejak zaman dahulu ikatan persaudaraan ini telah diterapkan oleh Raja Mataram, yaitu: Anak Agung Ngurah Karangasem. Menurut buku "Keris di Lombok", bahwa Raja Mataram (Lombok) selain terkenal kaya raya juga adalah raja yang ahli tata ruang kota, melaksanakan sensus penduduk kerajaan dengan meminta semua penduduknya mengumpulkan jarum. Penduduk laki-laki dan perempuan menggunakan jarum untuk menandakan suatu ikatan (DJelenga, 
2000). Oleh karena itu, jelas bahwa budaya kekerabatan ini sudah tertanam dari zaman dahulu, sehingga sebutan Semeton menyimbolkan kekuatan persaudaraan tersebut. Artinya, jelas nama "Si Meton" merupakan suatu adopsi dari kata Semeton yang dijadikan tema dalam desain karakter tersebut. Akan tetapi, pemahaman terhadap konsep keindahan seperti demikian belum banyak yang memahaminya, sehingga hal ini sangat perlu dilakukan penelitian dan pengkajian lebih mendalam, agar bentuk daya tariknya dapat diketahui.

Desain karakter merupakan rancangan yang berbentuk manusia, hewan, alien, atau penggabungan dari ketiganya. Desain dituliskan dalam Encyclopedia of The Art, merupakan sebuah dorongan keindahan yang diwujudkan dalam suatu bentuk komposisi; rencana komposisi; sesuatu yang memiliki kekhasan; atau garis besar suatu komposisi (Sachari, 2005). Komposisi bentuk, baik bentuk manusia, hewan maupun Alien disusun berdasarkan komposisi yang diinginkan, sehingga terbentuk menjadi suatu desain karakter yang berbeda dari bentuk karakter pada umumnya. Karakter diistilahkan sebagai suatu kepribadian (Djalle, 2007). Sementara Smardon secara umum mengungkapkan bahwa karakter adalah salah satu atribut atau ciri yang membuat objek dapat dibedakan sebagai sesuatu yang sifatnya sangat individual (Aryani, Santosa, dan Zpalanzani, 2013; Anggara, Santosa, dan Udayana, 2019). Kepribadian atau individu yang menggambarkan suatu kesan menarik dalam suatu desain karakter. Akan tetapi, kesan yang menarik tersebut belum tentu dapat dipahami kebanyakan masyarakat. Baik dari bentuk maupun citra yang memberikan kesan menarik pada benak penikmat atau masyarakat. Oleh karena itu, desain karakter "Si Meton" menarik diteliti, karena diduga memiliki daya tarik dari visual maupun perannya.

Berdasarkan uraian diatas yang melatarbelakangi penelitian ini, maka muncullah inti permasalahan. Terutama tentang bagaimana daya tarik desain karakter "Si Meton" dalam menciptakan kesan dan pesan melalui visualnya. 
Penelitian ini adalah bagian kecil dari tesis, yang bertujuan untuk menganalisis daya tarik dari sudut pandang konsep estetika postmodern dalam desain karakter "Si Meton". Manfaat penelitian ini sebagai pemahaman tentang idiom estetika postmodern yang ditimbulkan melalui peminjaman unsur budaya dan karya masa lalu yang mengarah pada prinsip form follow fun; juga sebagai landasan dalam mempelajari karakteristik peranan desain karakter "Si Meton" yang menimbulkan kesan estetik dan baru. Selain itu, sebagai acuan bagi penelitian selanjutnya agar mampu mengembangkan ke ranah pemahaman yang lain. Melalui penelitian ini, dapat ditemukan daya tarik nostalgia terhadap budaya masa lalu dan daya tarik ambassador berupa parodi dari bentuk "Si Meton" yang mengandung pesan dan kesan promosi kepada masyarakat Nusa Tenggara Barat.

\section{METODE PENELITIAN}

Metode yang digunakan dalam penelitian ini adalah metode kualitatif. Metode ini dinamakan sebagai metode artistik, karena proses penelitian lebih bersifat seni, dan disebut sebagai metode interpretatif, karena data hasil penelitian lebih berkenaan dengan interpretasi terhadap data yang ditemukan di lapangan (Sugiyono, 2018). Penelitian ini juga dilengkapi dengan teknik pengumpulan data seperti: observasi, wawancara dan dokumentasi. Sumber data dikumpulkan melalui hasil observasi dan hasil wawancara kepada R. Fani Printi Ardi (36 tahun) desainer karakter "Si Meton", Sutarso (36 tahun) pekerjaan desainer grafis dan desainer karakter animasi LinkMedia Mataram, Ahmad Badrul Ula (30 tahun) pekerjaan akademisi dalam bidang seni budaya, serta Lalu Rahman Hadi (48 tahun) pekerjaan Budayawan Nusa Tenggara Barat dan seniman pamor atau datu pelet keris Lombok; serta hasil dokumentasi yang dikumpulkan dari sumber-sumber yang berkaitan atau 
yang relevan dari buku, artikel, website dan lainnya. Analisis data dilakukan melalui tahapan reduksi data, penyajian data dan penarikan kesimpulan.

Pada saat analisis, juga diperlukan landasan teori yang menjadi penguat dalam hipotesis yang dilakukan. Landasan yang digunakan dalam penelitian ini adalah teori estetika postmodern Piliang dan teori prinsip animasi Walt Disney. Jean Baudilard, Foucault, Sontag, Rorty, Deleuze dan lainya merupakan tokoh sebagai dasar utama Piliang mengembangkan idiom estetika postmodern ini, lebih ditinjau dari pemanfaatan/ peminjaman unsur budaya dan karya masa lalu yang diolah secara daya tarik estetik melalui penekan bentuk pelesetan dan kritikan. Idiom estetik tersebut, dikategorikan sebagai pastiche, parodi, kitsch, camp, dan skizofrenia (Piliang, 2012). Idiomidiom tersebut lebih mengarah dari prinsip postmodern yaitu: Fun Follow Fun. Teori ini hadir sebagai pemecahan daya tarik estetik desain karakter "Si Meton" yang menekankan pada idiom estetika visualnya. Akan tetapi, idiom yang digunakan antara lain seperti: pastiche dan parodi. Kesan yang menarik perhatian di dalam desain karakter ini perlu diungkap agar terjadi pemahaman bagi masyarakat luas. Analisis hasil penelitian ini juga didukung oleh teori prinsip penggambaran karakter animasi yang dikeluarkan Walt Disney. Dalam buku Art of Animation, Walt Disney menuliskan 12 prinsip animasi yaitu: Pose to Pose, Timing, Stretch \& Squash, Anticipation, Secondary Action, Follow Through \& overlapping Action, Easy In \& Easy Out, Arch, Exaggeration, staging, Appeal, dan Personality (Djalle, 2007). Akan tetapi, tidak semua prinsip yang digunakan menekankan pada Appeal, karena mengingat desain karakter "Si Meton" hanya diam berbentuk maskot.

Berdasarkan penelitian sebelumnya tentang desain karakter "Si Meton", yang termuat dalam Jurnal Imajinasi Vol XII no 2 Juli 2018. Hal. 4955. Penelitian ini, membahas tentang tahap perancangan karakter "Si Meton" sebagai maskot Pilkada Nusa Tenggara Barat tahun 2018. Akan tetapi, 
perbedaannya dengan penelitian yang peneliti lakukan, lebih mengkaji dan mengkritisi dari segi daya tarik yang dihasilkan dari unsur kebudayaan Nusa Tenggara Barat. Agar tidak terjadi salah tafsir, atau salah interpretasi kebudayaan yang memiliki pakem serta aturan yang terstruktur dalam kehidupan masyarakat Nusa Tenggara Barat.

\section{HASIL DAN DISKUSI}

Hasil observasi pada desain karakter "Si Meton" dapat dirincikan, terdapat beberapa unsur budaya yang dipinjam dari karya dan budaya terdahulu. Unsur budaya tersebut menjadi daya tarik promosi pada Pilkada Nusa Tenggara Barat Tahun 2018. Daya tarik tersebut, mengarah pada patron dan plesetan yang bertujuan sebagai kritik atau protes terhadap Golongan Putih (Golput).

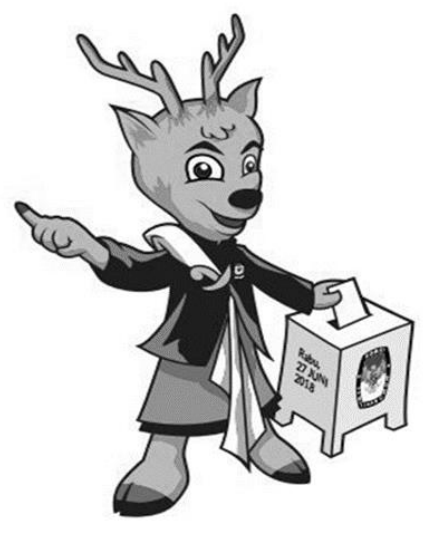

Gambar 1. Desain karakter "Si Meton" Sumber Gambar: Hasbullah, 2018

Gambar 1 di atas, merupakan bentuk desain karakter "Si Meton" pada maskot Pilkada Nusa Tenggara Barat tahun 2018. Desain karakter "Si Meton" memiliki daya tarik yang estetis yang tampak dari visualnya. Daya tarik tersebut, memiliki eksistensi yang indah dari hasil distorsi suatu bentuk alam atau benda. Keindahan bentuk lebih mengarah pada prinsip form follow fun 
terlihat dari visual yang bergaya berlebihan. Gaya tercipta dari penggabungan bentuk yang dicampur aduk menjadi suatu bentuk yang baru. Menurut Genova, gaya diciptakan melalui perkawinan antara bentuk dan kandungan isi, dengan cara tertentu sehingga bentuk mengekspresikan, yaitu secara metaforis menggambarkan kandungan isi (Piliang, 2012). Gaya dari hasil ekspresi pada desain karakter "Si Meton" menggambarkan kandungan makna yang mengkomunikasikan maksud dan tujuan dari maskot tersebut. Untuk itulah perlunya penggunaan gaya bahasa visual dalam iklan yaitu untuk memberikan daya tarik terhadap konsumen (Wirasari dan Karo, 2018).

Media promosi Pilkada Nusa Tenggara Barat, Karakter "Si Meton" diharapkan mampu membangun identitas brand pada kegiatan tersebut. Hal serupa dikatakan Caufield, bahwa membuat sebuah karakter pada brand atau merek, yang biasa disebut dengan maskot, adalah cara yang bagus untuk membangun identitas brand dan menarik perhatian publik (Jhalugilang, 2018). Sebagai menarik perhatian publik, desain karakter "Si Meton" dalam maskot Pilkada Nusa Tenggara Barat tahun 2018 sangat perlu dikaji berdasarkan hal-hal yang membuat suatu keindahan. Keindahan dilihat dari tampilan visual desain karakter tersebut, menggambarkan suatu pengalaman terhadap kebudayaan setempat. Kebudayaan yang berwujud berupa unsur dalam desain karakter "Si Meton" menjadi kesatuan utuh membentuk daya tarik yang estetik.

\section{Daya Tarik "Si Meton"}

Kemenarikan desain karakter, tampak pada bagian-bagian yang menggambarkan tempat tertariknya seorang pengamat atau publik. Publik menurut pandangan filsafat seni (Sumardjo, 2000), bahwa tidak selalu seluruh masyarakat, tetapi hanya sebagian saja. Sebagian masyarakat dikatakan publik seni, karena tidak semuanya memahami masalah seni atau desain. 
Pemahaman masalah desain karakter, tentu hanya dipahami oleh seorang desainer, animator, seniman dan para pengamat budaya. Oleh karena itu, desain karakter "Si Meton" memiliki daya tarik yang indah, jika ditelaah atau diamati lebih detail. Menurut Sutarso (36 tahun) desainer dan animator PT. Link Media Advertising Mataram, mengatakan “...bagian daya tarik "Si Meton” tepat pada tinta yang ada pada jarinya" (wawancara, 22 Februari 2020). Pada bagian tinta biru pada jari kelingking tangan kanan desain karakter "Si Meton", merupakan salah satu bagian strategi dalam mempromosikan kegiatan Pilkada Nusa Tenggara Barat tahun 2018 yang lalu. Strategi tersebut menggambarkan suatu peringatan, bahwa melalui desain karakter "Si Meton" dalam maskot Pilkada Nusa Tenggara Barat diharapkan mengurangi angka kelompok Golongan Putih (Golput). Hal tersebut diidentikan oleh Bill Gates sebagai Enlighten atau pencerahan. Pencerahan dengan hal-hal yang positif akan mengobati dahaga khalayak, sehingga menjadi pusat perhatian (Budiman, 2008). Pusat perhatian yang dimaksud adalah intisari dari visual yang disampaikan pada desain karakter "Si Meton".

Faktor-faktor yang menyebabkan desain karakter "Si Meton" menjadi menarik perhatian dalam Pilkada Nusa Tenggara Barat tahun 2018 antara lain seperti: pengalaman audiens, ikonik, dan unik. Kricfalusi, seorang desainer karakter, animator dan pengisi suara mengatakan, bahwa ada beberapa faktor yang membuat desain karakter mampu bertahan lama, ikonik, dan masuk dalam segala bidang (Ramadhana, Mansoor dan Haswanto 2013). Desain karakter "Si Meton" dapat bertahan lama, apabila desain karakter tersebut dapat dikenali oleh audiens atau masyarakat (tidak asing). Faktorfaktor yang menyebabkan suatu desain karakter dapat memberikan informasi melalui indera visual. Sebagaimana dikatakan Alina Wheeler bahwa indra penglihatan memberikan lebih banyak informasi tentang dunia dibandingkan dengan panca indra lainnya (Hidayat dan Rosidin, 2018). Informasi yang 
disampaikan melalui visual, memberikan gambaran tentang kegiatan yang diiklankan desain karakter "Si Meton". Iklan menurut Wright yang dikutip oleh Alo Liliweri sebagai bentuk penyampaian pesan sebagaimana kegiatan komunikasi lainya (Widyatama, 2007). Pesan verbal yang disampaikan desain karakter "Si Meton" dalam maskot Pilkada Nusa Tenggara Barat, merupakan informasi untuk mempengaruhi masyarakat, agar ikut berpartisipasi menggunakan hak pilihnya dalam kegiatan Pilkada tahun 2018 yang lalu.

Keindahan desain karakter "Si Meton", menjadi bagian daya tarik visual yang menggugah pemahaman unsur-unsur yang terdapat di dalamnya. Sebagai bentuk yang mengalami sentuhan antropomorfik, membuat visual menjadi wujud peminjaman unsur. Unsur yang dipinjam berupa budaya dan karya masa lalu terbentuk menjadi wujud kebaruan yang segar. Bentuk kebaruan yang terbentuk dari ambassador-ambassador atau pelesetan. Pelesetan sebagai ruang kritik untuk mengungkap perbedaan dalam suatu lingkup budaya. Hal ini diidentikkan oleh Linda Hutcheon sebagai bentuk parodi (Piliang, 2012).

\section{Parodi}

Bentuk pelesetan yang lebih berkembang dalam media komunikasi yang mengarah pada visual yang janggal. Bentuk kejanggalan pada karakter "Si Meton", tampak pada visual yang dirancang dengan pengkombinasian bahasa visual dari unsur budaya dari etnik lainnya. Pengkombinasian bahasa visual yang berbeda, membentuk suatu imitasi dalam bentuk humor. Sebagaimana dikatakan Ardi (36 tahun) desainer karakter "Si Meton", “...konsep yang diterapkan dalam mendesain karakter ini, lebih mendekatkan pada ambassador untuk mencapai tujuan ke segala target sasaran" (Wawancara, 24 Maret 2020). Target sasaran lebih menjangkau pada kaum milenial yang peduli membangun. Pembangunan generasi milenial kurang 
lebih dekat pada karakteristik budaya masa lalu yang dipinjam atau diduplikasi. Hal serupa dituliskan The Oxford English Dictionary tentang definisi parodi “...sebagai pemikiran dan ungkapan karakteristik dalam diri seorang (desainer) atau kelompok pengarang diimitasi sedemikian rupa untuk membuatnya tampak absurd, khususnya dengan melibatkan objek lucu dan janggal" (Piliang, 2012). Kelucuan bentuk menjangan yang diolah seorang desainer menjadi desain karakter "Si Meton", tampak pada bentuk yang tak biasa dilihat dalam realitas hidupnya. Kebiasaan hewan menjangan biasa hidup berkelompok, bersatu membentuk kekuatan dalam menghadapi permasalahan sehari-hari.

Bentuk keindahan parodi, lebih mengarah pada prinsip postmodern yaitu form follow fun. Prinsip ini cenderung mengarah pada bentuk struktur dan makna yang ironis. Oleh sebab itu, Mikhail Bakhtin memperbincangkan parodi sebagai satu bentuk representasi, akan tetapi representasi yang lebih ditandai oleh pelencengan, penyimpangan, dan pelesetan makna atau representasi palsu (Piliang, 2012). Hal serupa disampaikan Sumbo dalam (Tinarbuko, 2013), parodi adalah salah satu bentuk representasi. Uniknya, representasi tersebut selalu ditandai dengan sifat pelencengan, penyimpangan, dan pelesetan makna, atau jamak disebut dengan representasi palsu. Artinya, keindahan parodi berlandaskan pada prinsip form follow fun. Keindahan parodi sebagai daya tarik pada desain karakter "Si Meton" yang menekankan pelesetan, kritikan serius, humor, dan permainan bentuk dari unsur kearifan lokal yang ada.

Beberapa teks yang terbentuk menjadi satu kesatuan dalam desain karakter "Si Menton" yang membentuk suatu target sasar sebagai komunikasi visual di Pilkada Nusa Tenggara Barat tahun 2018. Hal ini dikatakan oleh Marc Gobe sebagai branding yang menyentuh secara emosional (Ardi dan Wiratama, 2018). Emotional branding yang dipaparkan Gobe, bertujuan 
untuk membentuk identitas suatu kegiatan khususnya sebagai promosi KPUD Nusa Tenggara Barat dalam mensosialisasikan kegiatan Pilkada.

\section{Pastiche}

Bentuk daya tarik karakter "Si Meton" juga dilihat dari unsur budaya masa lalu yang dipinjam dan dikembangkan menjadi wujud desain yang baru. Unsur budaya yang dipinjam berupa pakaian adat untuk laki-laki suku Sasak. Hal ini berkaitan yang disampaikan oleh Lalu Rahman Hadi (48 tahun) seorang budayawan, menyambung lidah dari $\mathrm{H}$. Lalu Djelenga tentang kehidupan sosial budaya masyarakat yang masih teguh memegang tradisi dalam menunjukkan identitasnya, sampai saat ini, apabila menyangkut upacara resmi, terlebih lagi pelaksanaan adat, hampir seluruh suku bangsa di Nusantara ini, menempatkan keris sebagai perlengkapan pakaian daerah (Wawancara, 24 Maret 2020). Pakaian adat pria Sasak banyak digunakan pada acara resmi pemerintahan, upacara adat dan acara resmi lainnya. Perkembangan pakaian adat pria Sasak Lombok, dipengaruhi oleh kemajuan zaman, sekarang sudah dilengkapi oleh PEGON/PAGONGAN yang merupakan adaptasi dari Eropa. PEGON mirip seperti Jas merupakan pengaruh budaya luar akibat transformasi budaya yang sangat statis.

Bentuk pakaian pria Sasak Lombok yang dipinjam sebagai pakaian karakter "Si Meton" yang sudah dipengaruhi oleh budaya Eropa. Pengaruh budaya Eropa terhadap pakaian pria Sasak, mirip seperti jas atau yang disebut PEGON. Unsur budaya yang dipinjam dan direkonstruksi menjadi karya atau desain baru dikatakan (Piliang, 2012), sebagai keindahan pastiche. Keindahan pastiche sebagai bentuk idiom estetika postmodern yang digunakan sebagai bagian atau unsur dalam karya seni dan desain. Bentuk keindahan pastiche menurut pandangan Umberto Eco sebagai patronisasi yang direkonstruksi sebagai bentuk replika murni atau duplikasi dari kebudayaan atau karya masa 
Ialu (Piliang, 2012). Artinya, patronisasi atau mengulang bentuk budaya masa lalu, dapat dijadikan suatu kebaruan yang menjadikan visual tersebut menarik. Daya tarik atau yang biasa disebut eye catching dalam karya seni dan desain, membuat penikmat atau masyarakat menjadi nostalgia terhadap budaya masa lalu.

Keindahan berpengaruh ke nostalgia terhadap budaya atau karya masa lalu, menjadikan desain karakter "Si Meton" memiliki daya tarik yang estetik. Daya tarik tersebut, biasa dikaitkan dengan yang humoris dan tidak biasa ditemukan di dalam kehidupan sehari-hari. Akan tetapi, ada kaitannya dengan budaya keseharian dalam kehidupan masyarakat. Hal ini terkait dengan disampaikan bahwa suatu bentuk humoris yang diciptakan oleh orang dalam masyarakat sebagai sarana untuk mencapai suatu tujuan atau menyampaikan suatu maksud (Gie, 2004). Terkait dengan daya tarik desain karakter "Si Meton", terlihat sebagai bentuk lelucon yang humoris menyampaikan maksud berkaitan dengan pilkada Nusa Tenggara Barat tahun 2018. Tujuan lelucon ini terkait dengan apa yang dikatakan R. Fani Printi Ardi (36 tahun), bahwa maksud dan tujuan "Si Meton" didesain dalam bentuk yang humoris, agar semua kalangan masyarakat yang memiliki hak untuk memilih dalam event pilkada di provinsi Nusa Tenggara Barat tahun 2018 (Wawancara, 24 Maret 2020). Oleh karena itu, desain karakter "Si Meton" dirancang sebagai ikon pilkada Nusa Tenggara Barat tahun 2018 yang memiliki daya tarik yang estetik.

Daya tarik desain karakter "Si Meton" sebagai ikonik kegiatan Pilkada Nusa Tenggara Barat tahun 2018, terbentuk dalam suatu prinsip gambar yang mengarah pada pandangan desain karakter animasi. Desain karakter animasi memiliki prinsip-prinsip yang menopang suatu tokoh dapat menyampaikan pesan dan kesan. Pesan dan kesan visual karakter "Si Meton" mampu membentuk suatu komunikasi kepada audiens atau masyarakat. Komunikasi 
yang dibentuk dari daya tarik karakter melalui tampilannya. Oleh karena itu, perlu dilakukan pembahasan tentang prinsip penggambaran animasi sebagai unsur daya tarik desain karakter "Si Meton". Paragraf selanjutnya akan mengkaji prinsip yang menjelaskan tentang daya tarik yang ada di dalam desain karakter "Si Meton".

\section{Appeal}

Kesan yang disampaikan karakter "Si Meton" dapat tercipta dari sudut pandang yang terdapat pada visual karakter. Hal senada dikatakan oleh (Djalle, 2007), bahwa appeal merupakan cara yang baik untuk menyampaikan suatu pesan dalam bentuk kesan yang menarik, cantik dan komunikatif dari sebuah karakter yang disampaikan. Berdasarkan visualnya, desain karakter "Si Meton" memiliki tanda-tanda yang dikomunikasikan dikemas secara menarik perhatian. Tujuan kemenarikan desain karakter ini untuk mengkomunikasikan kegiatan Pilkada Nusa Tenggara Barat tahun 2018. Sebagai media komunikasi, desain karakter "Si Meton" diharapkan mampu menyampaikan pesan dan kesan dari wujudnya. Wujud desain karakter ini, diolah menjadi lebih berkarakter dari unsur kearifan lokal yaitu hewan menjangan.

Hewan diangkat sebagai wujud dalam karakter "Si Meton" yang duplikasi dari logo provinsi Nusa Tenggara Barat dan dikembangkan menjadi bentuk yang baru yang lebih hidup. Di dalam konsep perancangannya, R. Fani Printi Ardi menerapkan antropomorfik untuk mendapatkan hasil yang lebih segar dan berkesan. Kenapa hewan, karena hidupnya selalu berkelompok dan membentuk kekuatan (Wawancara, 24 Maret 2020). Artinya, kesan yang dimuat dalam desain karakter "Si Meton" menunjukan kekuatan promosi KPUD Nusa Tenggara Barat tentang Pilkada yang akan dilaksanakan untuk memilih Gubernur dan Wakil Gubernur. Kesan karakter ini sebagai daya tarik yang ikonik bagi masyarakat provinsi Nusa Tenggara Barat. Ikon menjangan 
sudah menjadi referensi atau pengalaman bagi masyarakat umum di Nusa Tenggara Barat.

Berdasarkan uraian di atas, daya tarik melalui kesan desain karakter "Si Meton" membentuk kesan kekuatan dalam promosi Pilkada Nusa Tenggara Barat tahun 2018 silam. Hal ini menjadikan suatu bentuk kepedulian masyarakat Nusa Tenggara Barat untuk memanfaatkan hak pilihnya dalam kegiatan Pilkada tersebut. Melalui kegiatan Pilkada, desain karakter "Si Meton" mampu memiliki kekuatan dari unsur kearifan lokal. Kearifan lokal tersebut, memberikan muatan nilai-nilai baru sebagai teropong untuk melihat kehidupan dari sudut pandang yang berbeda (Budiman, 2008). Kekuatan kearifan lokal memberikan daya tarik yang indah pada kesan desain karakter "Si Meton". Daya tarik dari segi kesan dapat memberikan penguatan informasi yang estetik dari pengalaman dalam menikmati atau menilai karakter "Si Meton".

Pada visual karakter "Si Meton", memang pakaian adat yang digunakan pada acara resmi, terlihat Bebet terpasang menjadi Leang di pundaknya. Menurut Lalu Rahman Hadi (48 tahun) budayawan, mengatakan bahwa "... masalah budaya harus dikoreksi dari cara pasang keris dan busananya, kalau Singkur letaknya di belakang dan keris daerah lain bentuknya, kalau yang didesain tersebut gambar keris Jawa" (wawancara, 22 Februari 2020). Artinya, pakem pakaian adat Sasak, jika bentuk pakaiannya menggunakan Leang, maka penempatan keris diposisikan di belakang punggung disebut Singkur. Singkur sebagai bentuk keris yang digunakan untuk penghormatan dan kehormatan.

Penghormatan dan kehormatan yang digambarkan dalam karakter " $\mathrm{Si}$ Meton" yang ditujukan masyarakat Nusa Tenggara Barat agar ikut partisipasi dalam kegiatan pilkada tahun 2018 yang lalu. Kegiatan pilkada yang demikian menjadi ajang penarikan minat atau daya tarik partisipasi masyarakat melalui 
kontestasi identitas budaya di mana suatu kegiatan dilaksanakan. Kontestasi identitas budaya dilakukan untuk merebut hati pemilih untuk memilih calon pemimpinnya melalui ajang pilkada serentak pada tahun 2018. Menurut penelitian (Saleh, 2018), menyatakan bahwa realitas itu mengidentifikasikan bahwa kontestasi identitas yang gencar dilakukan orang Sasak dalam merebut hati pemilih dalam Pemilihan Umum Kepala Daerah 2018 bukanlah fenomena sederhana dan bersifat tunggal. Artinya, kontestasi identitas budaya dilakukan sebagai daya tarik yang indikasinya ke masa lalu yang penuh dengan pesan dan kesan bagi kehidupan di Nusa Tenggara Barat. Begitu juga yang tampak pada visual karakter "Si Meton" terdapat unsur budaya dari etnis Sasak, Samawa, dan Mbojo yang dituangkan dalam bentuk media maskot untuk merebut hati pemilih pada kegiatan pilkada tahun 2018 yang lalu.

Berdasarkan uraian di atas, maka daya tarik pada karakter "Si Meton" yang berfungsi sebagai maskot pilkada Nusa Tenggara Barat tahun 2018 terdapat pada konsep keindahan yang dimiliki. Namun dalam penggambarannya, "Si Meton" masih terdapat unsur-unsur budaya khususnya pakaian pria Sasak. Tetapi, tidak melepaskan diri dari daya tariknya sebagai media promosi dalam kegiatan pilkada tahun 2018. Secara visual, "Si Meton" mengindikasikan kontestasi identitas budaya etnis daerah Nusa Tenggara Barat. Hal tersebut, sebagai daya tarik merebut hati pemilih dalam kegiatan pilkada tahun 2018. Indikasinya, identitas budaya tersebut sebagai sebuah pesan dan kesan yang membawa masyarakat nostalgia terhadap masa lalu, sehingga melalui daya tarik tersebut desain karakter "Si Meton" mampu memenangkan sayembara dalam ajang yang diadakan KPUD Nusa Tenggara Barat tahun 2017. 


\section{KESIMPULAN}

Daya tarik desain karakter "Si Meton" dapat disimpulkan bahwa, karakter tersebut sebagai bahasa verbal yang ikonik merupakan suatu bentuk yang mengindikasikan sebuah ambassador. Ambassador yang merupakan konsep daya tarik kekinian yang mengarah pada prinsip Form Follow Fun. Hal tersebut, sangat identik dengan bentuk parodi yang merupakan bentuk yang semangat kekinian, baik berupa kritikan, protes terhadap rasa ketidakpuasan atau bahkan sebagai media promosi. "Si Meton" sendiri merupakan hasil dari bentuk yang diambil dari budaya masa lalu atau identitas budaya terdahulu, yang dibentuk menjadi visual yang memiliki kesan dan pesan dalam keindahan pastiche. Keindahan daya tarik pastiche sendiri sebagai bentuk yang membawa ke nostalgia terhadap masa lalu. Hal ini yang dijadikan strategi untuk merebut hati pemilih melalui visual karakter "Si Meton". Bentuk karakter "Si Meton" yang berlandaskan kepada prinsip Appeal sebagai strategi yang menimbulkan daya tarik visual yang berkesan. Hal tersebut, menjadikan "Si Meton" lebih berkarakter sesuai dengan perannya sebagai media promosi yang menarik perhatian pemilih dalam kegiatan pilkada Nusa Tenggara Barat tahun 2018. Diharapkan hasil penelitian ini, mampu memberikan gambaran tentang daya tarik desain karakter bagi penelitian berikutnya. Selain itu sebagai tambahan ilmu baru bagi penulis dan pembaca tentang keindahan karya desain yang mengarah pada kesan dan pesan yang disampaikan ke audiens.

\section{UCAPAN TERIMA KASIH}

Pelaksanaan penelitian ini, tak lepas dari pihak-pihak yang membantu dan mendukung dalam proses pengumpulan data maupun kebutuhan materil. Oleh karena itu, penulis menghaturkan terima kasih kepada: Kementerian Riset Teknologi dan Pendidikan Tinggi Republik Indonesia, 
Direktorat Riset dan Pengabdian Masyarakat (DRPM), Direktorat Jenderal Penguatan Riset dan pengembangan, Rektor ISI Denpasar, LP2MPP ISI Denpasar, Kaprodi Program Magister Pascasarjana ISI Denpasar, Para Narasumber dan Segenap Tim Peneliti.

\section{DAFTAR PUSTAKA}

Anggara, I.G.A.S., Santosa, H., dan Udayana, A.A.G.B. (2019) 'Character Education and Moral Value in 2D Animation Film Entitled "Pendeta Bangau"', Capture: Jurnal Seni Media Rekam, 10(2), pp. 57-70.

Anggraini S., L. dan Nathalia, K. (2014) Desain Komunikasi Visual: Dasar-Dasar Panduan Untuk Pemula. Bandung: Nuansa Cendikia.

Ardi, R. F. P. dan Wiratama, D. A. (2018) 'Perancangan "Si Meton" sebagai Maskot Pilkada Provinsi Nusa Tenggara Barat 2018', Jurnal Imajinasi, 12 (2), pp 49-55

Aryani, D. I., Santosa, I. dan Zpalanzani, A. (2013) 'Kajian Transformasi Visual Desain Karakter Eevee pada Game Pokémon Series Generasi I-V', ITB Journal of Visual Art and Design, 5(2), pp. 155-175. doi: 10.5614/itbj.vad.2013.5.2.5.

Budiman, M. A. (2008) Jualan Ide Segar: Membangun Bisnis Ide Miliaran Rupiah Tanpa Modal. Yogyakarta: Galang Press.

Budiwanti, E. (2018) 'Pawai Ogoh-Ogoh Dan Nyepi Di Pulau Seribu Masjid: Penguatan Identitas Agama Di Ruang Publik', Harmoni, 17(2), pp. 208227. doi: 10.32488/harmoni.v17i2.319.

Djalle, Z. G. (2007) The Making of 3D Animation Movie Using 3DStudioMax. Revisi. Bandung: Informatika.

DJelenga, L. (2000) Keris Di Lombok. Mataram: Yayasan Pusaka.

Gie, T. Li. (2004) Filsafat Keindahan. Kedua. Yogyakarta: Pusat Belajar Ilmu Berguna (PBIB).

Hidayat, S. dan Rosidin, M. (2018) 'Visualisasi Desain Karakter Mahasiswa Jurusan Desain Komunikasi Visual Pada Papan Permainan Kuliah Seni \& Desain', Desain Komunikasi Visual, Manajemen Desain dan Periklanan (Demandia), 3(02), p. 136-148. doi: 10.25124/demandia.v3i02.1552.

Jhalugilang, P. (2018) 'Maskot Asian Games 2018 Sebagai Sebuah Brand', Jurnal Komunikologi, 15(2), pp 102-109.

Piliang, Y. A. (2012) Semiotika dan Hipersemiotika Kode, Gaya \& Matinya Makna. Bandung: Matahari.

Piliang, Y. A. (2019) Medan Kreativitas: Memahami Dunia Gagasan. 
Yogyakarta: Cantrik Pustaka.

Ramadhana, A.E., Mansoor, A.Z dan Haswanto, N. (2013) 'Kajian Daya Tarik Visual Pada Desain Karakter Pokémon', Jurnal Komunikasi Visual \& Multimedia, 5(2), pp. 93-105.

Sachari, D. A. (2005) Pengantar Metodologi Penelitian Budaya Rupa. Jakarta: Erlangga.

Saleh, M. (2018) 'Merebut Hati Pemilih: Kontestasi Simbol Budaya Orang Sasak Dalam Pemilihan Langsung Gubernur NTB Tahun 2018', in Hasil Penelitian. Mataram, p. 3. Available at: http://repository.uinmataram.ac.id/389/1/389 Laporan Penelitian.\%0Apdf.

Sugiyono, P. D. (2018) Metode Penelitian Kuantitatif, Kualitatif dan R\&D. Bandung: Alfabetha.

Sumardjo, J. (2000) Filsafat Seni. Bandung: ITB.

Sumaryono, E. (1999) Hermeneutik: Sebuah Metode Filsafat. Revisi. Yogyakarta: PT Kanisius.

Tinarbuko, S. (2013) 'Semiotika Desain Oblong Dagadu Djokdja', Jurnal ILMU KOMUNIKASI, 3(1), pp. 91-105. doi: 10.24002/jik.v3i1.243.

Widyatama, R. (2007) Pengantar Periklanan. Yogyakarta: Pustaka Book Publisher.

Wirasari, I. dan Karo, T.E.B.R. (2018) 'Kajian Gaya Bahasa Iklan Antangin Fit Pada Media Sosial', Desain Komunikasi Visual, Manajemen Desain dan Periklanan (Demandia), 3(02), pp. 145-159. doi: 10.25124/demandia.v3i02.1545. 